This manuscript is a preprint and has been submitted for publication to the Bulletin of Environmental Contamination and Toxicology.

Note that the manuscript has yet to be formally reviewed and may not be accepted. Subsequent versions may differ in content, depending on reviews.

The final version of this manuscript will be made available via the 'Peerreviewed Publication DOI' link to the right of this web page.

Please feel free to contact the authors; we welcome feedback. 


\title{
Use of geochemical and ecotoxicological approaches to evaluate sediment quality in differentially-contaminated, legally protected reserves along the coast of São Paulo State, Brazil
}

Capparelli, M.V ${ }^{\mathrm{a}}$; McNamara, J.C ${ }^{\mathrm{b}, \mathrm{c}}$; Araujo, G.S ${ }^{\mathrm{d}}$; Cruz, A.C.F. ${ }^{\mathrm{d}}$ and Abessa, D.M.S. ${ }^{\mathrm{d}}$

${ }^{a}$ Facultad de Ciencias de la Tierra y Agua, Universidad Regional Amazónica Ikiam, km 7 vía Muyuna, Tena, Napo, Ecuador

${ }^{b}$ Departamento de Biologia, Faculdade de Filosofia, Ciências e Letras de Ribeirão Preto, Universidade de São Paulo, Ribeirão Preto 14040-901, SP, Brazil

${ }^{c}$ Centro de Biologia Marinha, Universidade de São Paulo, São Sebastião 11600-000, SP, Brazil

${ }^{\mathrm{d}}$ Universidade Estadual Paulista, Campus de São Vicente, São Vicente 11380-972, SP, Brazil

Key words: sediment quality, geochemical and toxicity analyses, legally protected reserves, differential contamination, São Paulo state coast.

Running head: Sediment quality evaluation

\begin{abstract}
We compared sediment quality in estuaries at three locations along the coast of São Paulo State, Brazil, using geochemical analyses and whole sediment toxicity tests, performed during the southern winter and summer of 2013. Each locality is afforded a different degree of legal protection, and shows a distinct level of pollution: overall, Rio Diana (RD, most polluted, Permanent Protection Area) > Rio Itapanhaú (RI, intermediate contamination, Environmental Protection Area) $>$ Rio Picinguaba (RP, pristine, State Park). Chronic sediment toxicity tests were performed by evaluating reproductive rates of the copepod Nitokra sp. RI sediments exhibited the highest metal concentrations and toxicity in both seasons. Metal concentrations for RD were low but toxic in summer. RP sediments were not contaminated, suggesting effective legal protection from pollution at this locality. RI and RD, although afforded mild legal protection, showed clear signs of environmental degradation, emphasizing the need for more effective pollution control.
\end{abstract}




\section{Introduction}

Coastal regions and estuaries suffer from intense human occupation and anthropogenic activity that especially impact marine and estuarine ecosystems, owing to pollutant discharge. Most contaminants accumulate in sediments, producing toxic effects on the biota (Adams et al., 1992). Because sediments function as deposits of complex contaminant mixtures, interactions among xenobiotics can occur, producing unpredictable ecological effects (Swartz et al., 1988). Geochemical analyses and toxicity tests are frequently used to assess sediment quality in such estuarine and coastal ecosystems, identifying the nature and degree of contamination, allowing evaluation of sediment toxicity, and providing biological relevance.

Despite the importance of sediment quality assessments for environmental management, other means are also necessary, such as the establishment of protected areas to protect niches and habitats, ecological processes and biological diversity, and to maintain fisheries productivity. Kelleher (1999) defined Marine Protected Areas (MPA) as "any area of intertidal or subtidal terrain, together with its overlying water and associated flora, fauna, historical and cultural features, which has been reserved by law or other effective means to protect part or all of the enclosed environment". Different categories of MPAs have been

proposed, providing increasing restrictions on human presence and activities, in order to minimize anthropogenic impacts (IUCN, 1994). However, the effectiveness of different types of MPAs in protecting marine and estuarine environments from pollution is poorly known. Information on pollution is available for only 69 of 11,169 designated MPAs worldwide (Abessa et al., 2018), emphasizing the need for more inclusive studies.

The State of São Paulo in Southeastern Brazil includes $622 \mathrm{~km}$ of marine coastline and 11 coastal cities. The coastal region harbors a mosaic of uses, from pristine reserves afforded maximum legal protection to areas suffering intense anthropogenic pressure. Consequently, different levels of pollution occur along the coast, including some MPAs (CETESB, 2018). Establishing whether such MPAs remain uncontaminated and whether conservation policies have been effective in avoiding pollution constitutes an issue of foremost importance.

This study aims to evaluate the quality of sediments at three estuarine sites subject to distinct levels of anthropogenic impact and legal protection, using an integrated approach combining geochemical analyses and sediment toxicity testing. 


\section{Material and methods}

Study sites

Three estuarine sites subject to different degrees of legal protection and contamination were chosen: (i) Rio Diana (RD, $23^{\circ} 55^{\prime} 04.5^{\prime} \mathrm{S} ; 4^{\circ} 18^{\prime} 31.5^{\prime} \mathrm{W}$ ) and (ii) Rio Itapanhaú (RI, $23^{\circ} 50^{\prime} 0.2^{\prime \prime} \mathrm{S} ; 46^{\circ} 09^{\prime} 10.6^{\prime \prime} \mathrm{W}$ ), located in the Santos Estuarine System (SES) on the central

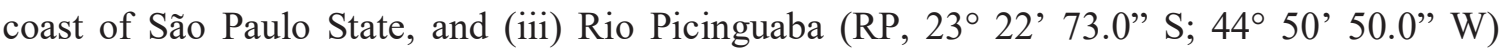
situated on the northern coast. All three sites are afforded baseline protection under the Brazilian Forest Code (Federal law \#12.651/2012), and are designated as Permanent Protection Areas (PPA), due to the presence of mangrove forests. However, this legal designation does not restrict various anthropogenic activities. Additionally, RI is part of the Marine Environmental Protection Area of the central coast of São Paulo, an MPA category that imposes mild restrictions on a range of human activities, focused on reconciling conservation demands and anthropogenic impacts (São Paulo State decrees \#53526 and \#53528, 2008a,b). Rio Picinguaba lies within a State Park in which most anthropogenic activities are prohibited according to the Brazilian federal system of protected areas (Federal law \#9.985/2000).

The Rio Diana area suffers from severe anthropogenic pollution. Located within the central SES and consisting of an area of $2372 \mathrm{~km}^{2}$, it includes one of the most populous and industrialized regions of São Paulo state (IBGE, 2007), and incorporates the Port of Santos. The estuary was once considered amongst the most polluted in the world (CETESB, 1985) due to multiple pollution sources, such as uncontrolled urbanization, port and industrial activities and agricultural inputs such as fertilizers and pesticides. Despite programs to control and reduce pollution, many sectors of the SES remain severely polluted (Abessa et al., 2019; Lamparelli et al., 2001; Pereira et al., 2016; Santos et al., 2018).

The Rio Itapanhaú estuary that delimits the northern edge of Bertioga, is also part of the SES, although it is considered to be in a better state of conservation (Eichler et al., 2006). Metal contamination has not has not been encountered in sediments near the river itself (Gonçalves et al., 2013), although local fiddler crabs show high metal concentrations in their soft tissues (Capparelli et al., 2016, 2019). The main threats to this estuary include the urban growth of Bertioga, erosion of mangrove forest margins by boat traffic, pollution from marinas, fishing terminals, sewage and urban drainage (Cunha et al., 2017; Cunha-Lignon et al., 2009c). The Rio Picinguaba is situated on the northern São Paulo coast near Ubatuba and lies within the Serra do Mar State Park (São Paulo State decree \#10.251, 1977), an even more restrictive protected area aimed at conserving the Atlantic rainforest and its associated ecosystems. 
Sediment sampling surveys at the three sites were undertaken during the southern winter (June) and summer (January) of 2013. About $150 \mathrm{~g}$ of surface sediment were collected from sand banks in each estuary. The samples were transferred to $50-\mathrm{mL}$ falcon tubes and transported to the laboratory in an isoprene container. For metal analyses, aliquots were frozen at $-20^{\circ} \mathrm{C}$; for toxicity experiments, aliquots were refrigerated at $4{ }^{\circ} \mathrm{C}$ and tested within 10 days. Sediment granulometry, composition and elemental analyses

For the granulometric analyses, each sediment sample was kiln-dried at $60{ }^{\circ} \mathrm{C}$ for three days, then macerated and sieved using a sieve set of known mesh diameters. Sediment granulometry was classified according to the Wentworth scale (Wentworth, 1922).

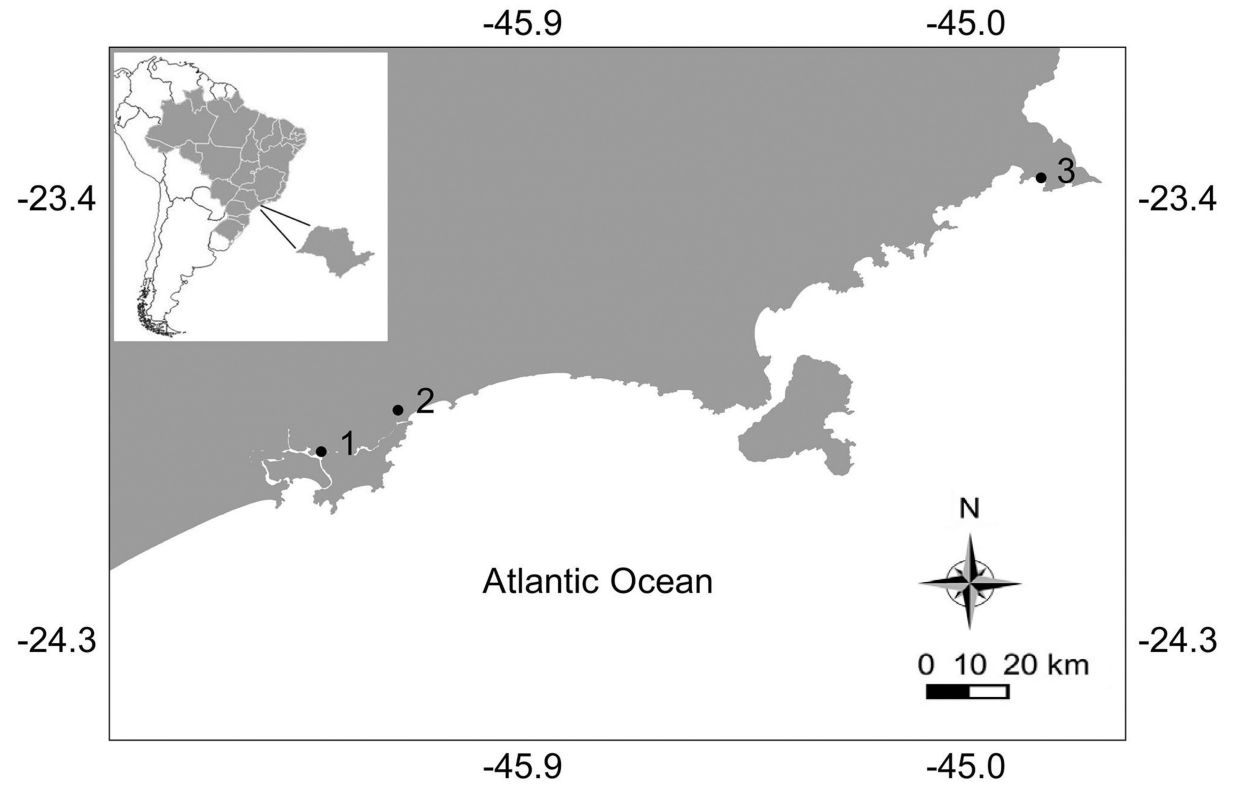

Figure 1. Sediment sampling sites (1, Rio Diana, Santos, $23^{\circ} 55^{\prime} 04.5^{\prime \prime} \mathrm{S} ; 46^{\circ} 18^{\prime} 31.5^{\prime \prime} \mathrm{W}$; 2 , Rio Itapanhaú, Bertioga, $23^{\circ} 50^{\prime} 0.2^{\prime}$ ' S; $46^{\circ} 09^{\prime} 10.6^{\prime \prime} \mathrm{W}$; 3, Rio Picinguaba, Ubatuba, $23^{\circ} 22^{\prime}$ $73.0^{\prime} \mathrm{S} ; 44^{\circ} 50^{\prime} 50.0^{\prime} \mathrm{W}$ ) on the southeastern Atlantic coast of the State of São Paulo, Brazil.

Calcium carbonate $\left(\mathrm{CaCO}_{3}\right)$ was analyzed following digestion of duplicate, previouslydried, 2-g aliquots in 50\% hydrochloric acid for $16 \mathrm{~h}$. The difference between the initial and final sample masses provides the $\mathrm{CaCO}_{3}$ content, and is given as a percentage.

Total organic matter (TOM) was analyzed following the method of Loring \& Rantala (1992). Duplicate, 10-g sediment samples, previously oven-dried at $60{ }^{\circ} \mathrm{C}$ for 3 days, were heated in a muffle furnace at $500{ }^{\circ} \mathrm{C}$ for $3 \mathrm{~h}$. The percentage TOM was calculated from the difference between the initial and the final masses.

For elemental analyses, the sediment samples were digested using a microwave-assisted decomposition system (Milestone MSL Ethos Synth 1600, Sorisole, Italy) as follows: 0.10 to $0.25 \mathrm{~g}$ of each sample was weighed in a PTFE flask and $4 \mathrm{~mL} \mathrm{HNO}_{3} / \mathrm{H}_{2} \mathrm{O}_{2}(2 \mathrm{~mL} 14 \mathrm{~mol} / \mathrm{L}$ 
$\left.\mathrm{HNO}_{3}+2 \mathrm{~mL} \mathrm{30 \% (v/v)} \mathrm{H}_{2} \mathrm{O}_{2}\right)$ were added. The flasks were sealed and a specific heating program (Nardi et al., 2009) was used to decompose the samples for $\approx 30 \mathrm{~min}$.

The elements were identified and quantified by mass spectrophotometry using a plasma source (Elan DRC II ICP-MS, Perkin Elmer, CT, USA). All reagents were of analytical grade, except $\mathrm{HNO}_{3}$ and $\mathrm{HCl}$, which were previously purified using a quartz sub-boiling distillation system (Kürner Analysentechnik, Rosenheim, Germany). High purity deionized water was obtained from a Milli-Q water purification system (Millipore, MA, USA). All solutions were stored in high-density polyethylene bottles. Plastic materials were cleaned by immersion in $10 \%(\mathrm{v} / \mathrm{v}) \mathrm{HNO}_{3}$ for $24 \mathrm{~h}$, washed five times with Milli-Q water and dried in a class 100 laminar flow hood before use. Multi-element solutions containing $1.000 \mathrm{~g} / \mathrm{L}$ of each element (Perkin Elmer, CT, USA) were used to construct the calibration curves. The calculated limit of detection was $0.1 \mathrm{ng} \mathrm{g}^{-1}$.

\section{Sediment toxicity analyses}

Control sediments, together with the benthonic harpacticoid copepod Nitokra sp., were collected from Engenho D'Água beach ( $23^{\circ} 47^{\prime} 15.40^{\prime} \mathrm{S} ; 45^{\circ} 21^{\prime} 48.65^{\prime}$ W) facing the São Sebastião Channel on São Sebastião Island, São Paulo State, Brazil. This is an area of high marine biodiversity (Rizzo and Amaral, 2001) and low sediment contamination and toxicity (Melo and Nipper, 2007). After sieving (1 mm ø mesh) and washing in filtered seawater, the copepods were separated, cultured in dilute seawater at $16 \pm 1 \% \mathrm{~S}$ and $25 \pm 2{ }^{\circ} \mathrm{C}$ under a $12 \mathrm{~h}$ light: $12 \mathrm{~h}$ dark photoperiod and fed with micro-algae twice a week (Lotufo \& Abessa, 2002). The sediments were stored at $4{ }^{\circ} \mathrm{C}$ and used as controls in the toxicity tests.

A whole sediment toxicity test using Nitokra sp. was employed to evaluate sediment toxicity according to Lotufo \& Abessa (2002). Four replicate samples of homogenized sediment of $\approx 2 \mathrm{~mL}$ each were placed in scintillation flasks, and $8 \mathrm{~mL}$ of dilute seawater $(19 \pm 2$ $\% \mathrm{~S}$ ) were added for a final volume of $10 \mathrm{~mL}$. After $24 \mathrm{~h}, 10$ ovigerous female copepods were separated from the copepod culture and introduced into each replicate. The test system was maintained in a constant temperature chamber at $25 \pm 2{ }^{\circ} \mathrm{C}$, under a $16 \mathrm{~h}$ light: $8 \mathrm{~h}$ dark photoperiod, without aeration, and the effects on copepod reproduction (number of nauplii and copepodites/female) were assessed on day 10.

The test copepods were fed at the beginning of the experiment by adding $100 \mu \mathrm{L}$ of a yeast/water mixture. At the end of the experiment, the contents of each replicate were fixed in $10 \%$ formalin, stained with Rose Bengal stain and analyzed. Physico-chemical parameters were measured at the beginning and end of the experiments, i. e., dissolved oxygen and 
temperature (Digimed DM-4P, São Paulo, Brazil), pH (Lutron PH-206 pH meter, Taipei, Taiwan) and salinity (Index Instruments US, Inc., FG-211 Portable Refractometer, Fl, USA). The copepods were sieved from the sediment using a 45- $\mu \mathrm{m} \varnothing$ mesh sieve, and examined under a stereomicroscope to identify and quantify the adult females and nauplii and copepodites.

\section{Statistical analyses}

The toxicological testing data were verified for normality of distribution and homoscedasticity using the Shapiro-Wilk and Bartlett tests, respectively. Toxicity effects were evaluated using a One-Way Analysis of Variance followed by Dunnett's multiple comparisons post-hoc t-test, employing an $\mathrm{R}$ software package. Effects and differences compared to the control sediment were considered significant at $\mathrm{P}=0.05$. The data were further analyzed using a principal components analysis.

\section{Results and Discussion}

Sediment composition and metal concentrations

The composition and metal concentrations measured in the sediments at sites from Rio Picinguaba (RP), Rio Itapanhaú (RI) and Rio Diana (RD) during the southern winter and summer of 2013 are provided in Table 1. All metals concentrations were below the toxic effect threshold (CCME, 2002). Only nickel in the RI sediment in summer was moderately high according to the regional sediment quality values proposed by Choueri et al. (2009). The percentage of $\mathrm{CaCO}_{3}$ ranged from 23 to $28 \%$ in most samples, except for RP in summer that reached $87.5 \%$.

Rio Picinguaba sediments showed the lowest percentages of TOM and exhibited considerable seasonal variation (3.5\% summer, $58 \%$ winter). At RI and RD, TOM varied from 60 to $70 \%$ during summer. The RP sediments were sandier ( $>90 \%)$ than at the other locations in both seasons. Congruently, sediments from RD and RI showed greater percentages of mud (29 to $40 \%$, and 16 to $27 \%$, respectively). The high TOM levels are indicative of depositional processes at all sites, while $\mathrm{CaCO}_{3}$ suggests marine influence. Muds, TOM and $\mathrm{CaCO}_{3}$ are geochemical carriers and are likely associated with the contaminant accumulation (Abessa et al., 2019; Cruz, et al., 2019). 
Table 1. Composition $\left(\mathrm{CaCO}_{3}\right.$, Total Organic Matter [TOM], and Sand and Mud, as percentages) and metal concentrations $\left(\mu \mathrm{g} \mathrm{g}^{-1}\right)$ in sediment samples from Rio Picinguaba, Ubatuba (State Park), Rio Itapanhaú, Bertioga (Marine Protection Area), and Rio Diana, Santos (Permanent Protection Area), collected during the southern winter and summer of 2013. The bold value indicates a metal concentration that exceeds the Canadian Environmental Quality Guidelines for sediments (CCME, 2002; Choueri et al., 2009).

\begin{tabular}{lrrrrrr}
\hline & \multicolumn{2}{c}{ Rio Pincinguaba } & \multicolumn{2}{c}{ Rio Itapanhaú } & \multicolumn{2}{c}{ Rio Diana } \\
\cline { 2 - 7 } & Winter & Summer & Winter & Summer & Winter & Summer \\
\hline CaCO3 & 28.6 & 85.7 & 25.1 & 27.8 & 25.6 & 23.7 \\
OM & 58.0 & 3.5 & 64.2 & 59.6 & 63.2 & 69.8 \\
Sand & 97.3 & 92.8 & 83.4 & 72.3 & 59.1 & 70.7 \\
Mud & 2.7 & 7.2 & 16.7 & 27.7 & 40.9 & 29.3 \\
Aluminum & 968.7 & $1,562.4$ & $4,041.5$ & $3,785.7$ & 428.2 & 296.3 \\
Arsenic & 0.9 & 1.1 & 0.9 & 0.4 & 0.4 & 0.1 \\
Barium & 2.4 & 1.8 & 18.9 & 30.3 & 2.3 & 2 \\
Cadmium & 0.0 & 0.0 & 0.0 & 0.2 & 0.0 & 0.0 \\
Lead & 1.2 & 1.1 & 5.8 & 3.9 & 2.2 & 1.5 \\
Cobalt & 0.6 & 0.6 & 1.7 & 2.0 & 0.2 & 0.1 \\
Copper & 0.9 & 1.2 & 3.2 & 4.2 & 1.3 & 1.6 \\
Chromium & 3.8 & 5.0 & 4.1 & 4.4 & 1.1 & 0.7 \\
Iron & $1,764.2$ & $2,374.2$ & $5,851.8$ & $5,170.7$ & 459.5 & 291 \\
Magnesium & 764.1 & 728 & 1321.6 & 1267 & 538 & 189.1 \\
Manganese & 11.2 & 15.0 & 7.2 & 61.0 & 2.7 & 3.6 \\
Nickel & 4.2 & 1.0 & 2.7 & 5.1 & 1.2 & 0.8 \\
Rubidium & 2.8 & 2.4 & 24.8 & 25.1 & 1.4 & 1.0 \\
Uranium & 0.2 & 0.2 & 1.8 & 0.8 & 0.4 & 0.1 \\
Vanadium & 11.5 & 3.0 & 19.7 & 25.8 & 14 & 14.1 \\
Zinc & 7.6 & 7.5 & 24.6 & 28.5 & 3.1 & 2.8 \\
\hline
\end{tabular}

\section{Sediment toxicity tests}

Physico-chemical parameters fell within acceptable ranges during the experiments (Lotufo \& Abessa, 2002) except for the low pH values for the RI site during both winter and summer ( $\mathrm{pH} 3$ and 1.2, respectively, see Supplementary Table 1). Low $\mathrm{pH}$ values may reflect the influx of acid leachate from a nearby garbage dumpsite. High sulfur titers, whose oxidation can generate $\mathrm{H}_{2} \mathrm{SO}_{4}$ also may be present, or organic matter from the surrounding mangrove forest, including humic and fulvic acids, or sewage, may have contributed to this low $\mathrm{pH}$ (Wren \& Stephenson, 1991, Schubauer-Berigan, 1993).

The toxicity test findings are given in Figure 2. The hatching rates of Nitokra sp. exposed to the sediments were significantly lower for the RI sediments in both winter and summer, and for RD in summer. The toxicity of the RD sediments in summer may be related to the high 
TOM concentrations $(69 \%)$ that can accumulate toxic contaminants. The toxicity of the RI sediments may derive from the overall higher metal concentrations at this site, although only Ni exceeded the threshold guidelines, in addition to the low $\mathrm{pH}$ (see Supplementary Table 1). In this more acidic environment, metals may not be in a steady-state equilibrium, and may be bioavailable and toxic.

\section{Integrated PCA analysis}

The first two principal components explained $\approx 83 \%$ of the total variance (Figure 3 ), PC1 accounting for $62.2 \%$. Most metals showed high positive correlations with PC1, while copepod fecundity correlated negatively, suggesting that metals contributed to toxicity. PC1 also separated RI (positive scores) from the other sites. Principal component 2 accounted for $22.8 \%$ of the variance and revealed an association of sediment factors with positive correlations for TOM and Mud, with a negative correlation for $\mathrm{CaCO}_{3}$ and toxicity and for As and Cr. Rio Diana and Rio Itapanhaú showed positive scores during summer and winter, and were associated with muddy and organically enriched sediments. Rio Picinguaba showed negative scores.

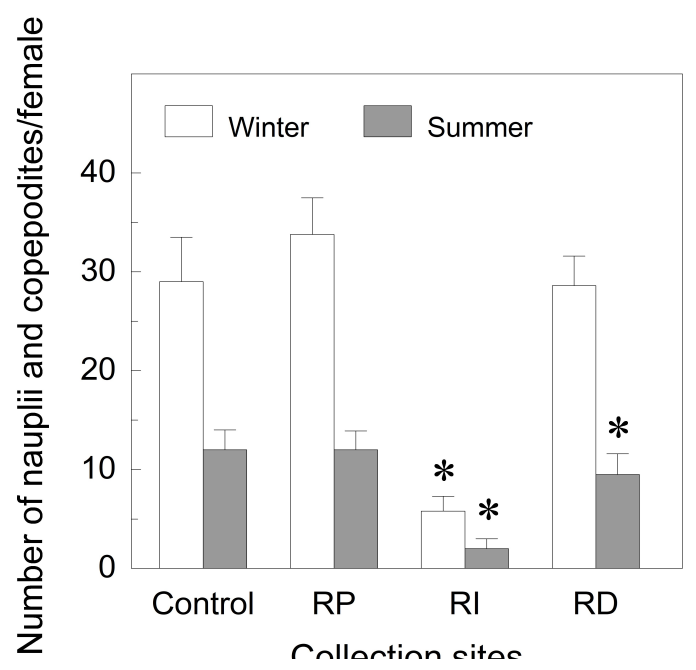

Figure 2. Chronic toxicity effects on copepod (Nitokra sp.) reproduction, using sediments collected from the Rio Picinguaba (RP), Rio Itapanhaú (RI) and Rio Diana (RD) during the southern winter and summer of 2013. Data are the mean $( \pm \mathrm{SEM}, \mathrm{N}=4$ ) hatching rates (total number of nauplii and copepodites divided by total number of females). ${ }^{*} \mathrm{P} \leq 0.05$ compared to the respective control group (sediment from Praia Engenho d'Água, São Sebastião Island). 


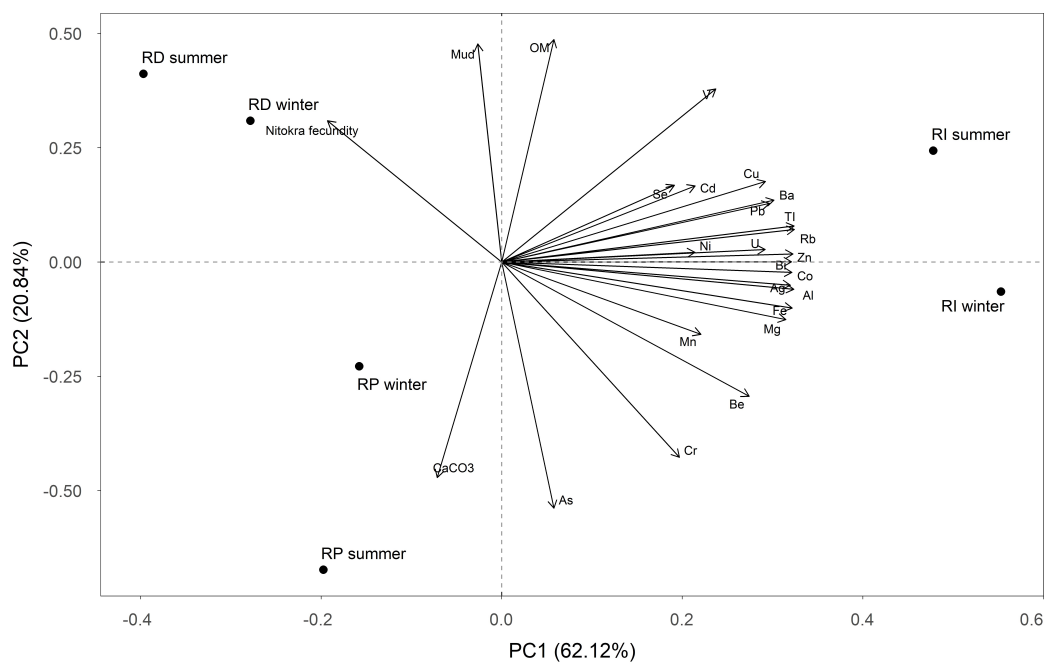

Figure 3. Principal components analysis of composition, elements and toxicity for sediment samples collected from Rio Diana (RD, severely contaminated site), Santos, Rio Itapanhaú (RI, moderately contaminated site), Bertioga, and Rio Picinguaba (RP, pristine site), Ubatuba, during the southern winter and summer of 2013.

The Rio Picinguaba site showed no relevant contamination. This area is subject to the most restrictive level of legal protection as a state park, and our findings suggest that the current protection policies are effective in avoiding pollution here. Lack of contamination and/or toxicity in marine and estuarine areas subject to more strict protective measures have been documented in other marine parks along the coast of São Paulo state (Moreira et al., 2019a; Abessa et al., 2017). However, alarming contaminant levels can be encountered (Moreira et al., 2019b).

Rio Diana is located within the SES, an area with a long history of environmental degradation (Abessa et al., 2019; Lamparelli et al., 2001; Luíz-Silva, 2002; 2006). Although the sediment quality of the main channels is well documented, few studies have addressed the tributaries and smaller inlets. We found no relevant metal contamination at the RD site, although sediment was toxic in the summer. Since the RD sediments showed a high TOM concentration, organic contaminants like polycyclic aromatic hydrocarbons (PAHs) may be present, causing the summer toxicity (Abessa et al., 2019; Gusso-Choueri et al., 2015, 2018). Rio Diana sediments are considered to be low to moderately degraded (Perina et al., 2018) and chronic toxicity is associated with Santos Port operations, which lead to high sediment concentrations of acenaphthene, acenaphthylene and lead. The northeastern segment of the SES that includes Rio Diana suffers the indirect influence of a large steel plant (Lamparelli et al., 2001), considered to be the main source of PAHs and some metals, together with 
discharges from fertilizer plants. Our findings show that the legal protection afforded by the Permanent Protection Area designation is not effective.

The sediments at the Rio Itapanhaú site were the most toxic and exhibited the highest concentrations of metals in both summer and winter. While below the thresholds of sediment quality guidelines, these metals appear to be bioavailable and cause toxicity. Although the Rio Itapanhaú estuary is separated from the more contaminated segments of the SES, its sediment quality is considered to be moderately impacted (Zaroni, et al., 2006; Pozo et al., 2011; Gonçalves et al., 2012; Moreira de Sousa et al., 2014; Ferraz et al., 2017). The Rio Itapanhaú area presents increasing degradation, exhibiting augmented levels of organic matter, fecal bacteria and contaminants like mercury and arsenic (CETESB, 2006; Lamparelli et al., 2001; Eduinetty Sousa et al., 2014; Ferraz et al., 2017). Thus, while protected by the Brazilian Forest Code as a PPA, and included in a less restrictive MPA, this area shows clear signs of environmental impact, revealing that these means of legal protection are ineffective. Other estuarine areas under similar protection show environmental contamination and toxicity such as the Cananéia-Iguape-Peruíbe Environmental Protection Area (Gusso-Choueri et al., 2015, 2018; Cruz et al., 2019) and Paranaguá Bay estuary (Choueri et al. 2009; Rodrigues et al., 2013).

Our findings also reveal that although the metal concentrations at the Rio Itapanhaú and Rio Diana sites are below the threshold limits of established quality guidelines, these sediments are toxic. We suggest that these limits for São Paulo state should be revised, considering our toxicity tests. We conclude further that the mere designation of estuarine localities as Permanent Protection Areas does not provide an effective safeguard, particularly in the case of the less restrictive MPAs.

\section{Declaration of competing interest}

The authors declare that they have no known competing financial interests or personal relationships that could influence the present investigation.

\section{Acknowledgments}

This investigation received financial support from the Fundação de Amparo à Pesquisa do Estado de São Paulo (\#2011/22537-0 to JCM) and from which MVC received a doctoral scholarship (\#2011/08065-9) (Postgraduate program in Comparative Biology, FFCLRP/USP). JCM (300662/2009-2) and DMSA (308649/2011) received Excellence in Research scholarships from the Conselho Nacional de Desenvolvimento Científico e Tecnológico, 
Brazil. We thank Lucas Gonçalves Morais for help in preparing the site map. Dr. Fernando

Barbosa kindly provided access to the metal analysis facility at the Departamento de Análises

Clínicas, Toxicológicas e Bromatológicas, FCFRP/USP, in Ribeirão Preto.

\section{References}

Abessa, D. M., Rachid, B. R., Zaroni, L. P., Gasparro, M. R., Pinto, Y. A., Bícego, M. C., Hortellan, M. A. Sarkis, J. E., Muniz, P., Moreira, L. B. \& Sousa, E. C. (2019) Natural factors and chemical contamination control the structure of macrobenthic communities in the Santos Estuarine System (SP, Brazil). Community Ecology, 20, 121-137.

Abessa, D. M., Vicente, T.M., Moreira, L.B., Morais, L.G., Cruz, A. C., Massoneto, M., Campos, B. G., Bícego, M. C., Taniguchi, S., Hortellani, M.A., \& Sarkis, J. E. (2017). Assessing the sediment quality of the Laje de Santos Marine State Park and other marine protected areas from the central coast of São Paulo (Brazil). Brazilian Journal of Oceanography, 65: 532-548.

Adams, S. M., Crumby, W. D., Greeley Jr, M. S., Ryon, M. G., \& Schilling, E. M. (1992). Relationships between physiological and fish population responses in a contaminated stream. Environmental Toxicology and Chemistry: An International Journal, 11, 1549-1557.

Brasil, 2000. Lei $\mathrm{N}^{\circ}$ 9.985, de 18 de Julho de 2000. Regulamenta o art. 225, § 1o, incisos I, II, III e VII da Constituição Federal, institui o Sistema Nacional de Unidades de Conservação da Natureza e dá outras providências. http://www.planalto.gov.br/ccivil_03/leis/19985.htm (accessed on August 1st, 2020).

CCME. (2002). Canadian environmental quality guidelines (Vol. 2). Canadian Council of Ministers of the Environment. https://www.ccme.ca/en/resources/canadian_environmental quality guidelines/

Capparelli, M. V., Abessa, D. M., McNamara, J. C. (2016) Effects of metal contamination in situ on osmoregulation and oxygen consumption in the mudflat fiddler crab Uca rapax (Ocypodidae, Brachyura). Comparative Biochemisty and Physiology Part C: Toxicology \& Pharmacology, 185:102-111.

Capparelli, M. V., Gusso-Choueri, P. K., de Souza Abessa, D. M., \& McNamara, J. C. (2019). Seasonal environmental parameters influence biochemical responses of the fiddler crab Minuca rapax to contamination in situ. Comparative Biochemistry and Physiology Part C: Toxicology \& Pharmacology, 216, 93-100.

CETESB. (2006). Águas interiores. Rede de monitoramento de qualidade das águas interiores do Estado de São Paulo. Relatórios. https://cetesb.sp.gov.br/aguas-interiores/publicacoes-e-relatorios/

Chapman, P. M. (1995). Ecotoxicology and pollution - key issues. Marine Pollution Bulletin, 31(4-12), 167-177.

Choueri, R. B., Cesar, A., Abessa, D. M., Torres, R. J., Morais, R. D., Riba, I., Pereira, C. D., Nascimento M. R., Mozeto, A. A., \& DelValls, T. A. (2009). Development of site-specific sediment quality guidelines for North and South Atlantic littoral zones: comparison against national and international sediment quality benchmarks. Journal of Hazardous Materials, 170(1), 320-331.

Cruz, A. C. F., Gusso-Choueri, P., de Araujo, G. S., Campos, B. G., \& de Sousa Abessa, D. M. (2019). Levels of metals and toxicity in sediments from a Ramsar site influenced by former mining activities. Ecotoxicology and Environmental Safety, 171, 162-172.

Cunha-Lignon, M., Coelho Jr, C., Almeida, R., Menghini, R., Correa, F., Schaeffer-Novelli, Y., ... \& Dahdouh-Guebas, F. (2009). Mangrove forests and sedimentary processes on the South of Coast of São Paulo State (Brazil). Journal of Coastal Research, 405-409.

Eichler, P. P. B., Eichler, B. B., David, C. J., de Miranda, L. B., \& Sousa, E. C. P. M. (2006). The estuary ecosystem of Bertioga, São Paulo, Brazil. Journal of Coastal Research, 1110-1113.

Ferraz, M. A., Alves, A. V., de Cássia Muniz, C., Pusceddu, F. H., Gusso-Choueri, P. K., Santos, A. R., \& Choueri, R. B. (2017). Sediment toxicity identification evaluation (TIE phases I and II) based on microscale bioassays for diagnosing causes of toxicity in coastal areas affected by domestic sewage. Environmental Toxicology and Chemistry, 36(7), 1820-1832.

Gonçalves, C., Figueira, R. C. L., Sartoretto, J. R., Salaroli, A. B., Ribeiro, A. P., Ferreira, P. A. D. L., \& Mahiques, M. M. D. (2013). Reconstruction of historical trends in potentially toxic elements 
from sediment cores collected in Bertioga channel, southeastern Brazil. Brazilian Journal of Oceanography, 61(2), 149-160.

Gusso-Choueri, P. K., de Araújo, G. S., Cruz, A. C. F., de Oliveira Stremel, T. R., de Campos, S. X., de Souza Abessa, D. M., ... \& Choueri, R. B. (2018). Metals and arsenic in fish from a Ramsar site under past and present human pressures: Consumption risk factors to the local population. Science of the Total Environment, 628, 621-630.

Kelleher, G. (1999). Guidelines for marine protected areas. IUCN, Gland, Switzerland and Cambridge, UK.

Lotufo, G. R., \& Abessa, D. M. S. (2002). Testes de toxicidade com sedimento total e água intersticial estuarinos utilizando copépodos bentônicos. Métodos em Ecotoxicologia Marinha: Aplicações no Brasil, Artes Gráficas e Indústria Ltda, São Paulo, 13, 151-162.

Luiz-Silva, W., Matos, R. H. R., Kristosch, G. C., \& Machado, W. (2006). Variabilidade espacial e sazonal da concentração de elementos-traço em sedimentos do sistema estuarino de Santos-Cubatão (SP). Química Nova.

Melo, S.L.R., Nipper, M. 2007. Sediment toxicity tests using the burrowing amphipod Tiburonella viscana (Amphipoda: Platyschinopidae). Ecotoxicology \& Environmental Safety 66: 412-420.

Moreira, L. B., Leite, P. R. B. D., de Lara Dias, M., de Castro Martins, C., \& de Souza Abessa, D. M. (2019). Sediment quality assessment as potential tool for the management of tropical estuarine protected areas in SW Atlantic, Brazil. Ecological Indicators, 101, 238-248.

Moreira, L.B.; Camargo, J.B.D.A.; Marques, B.B.; Martins, C.C.; Abessa, D.M.S. 2019b. Evaluating multiple lines of evidence of sediment quality in an urban Marine Protected Area (Xixová-Japuí State Park, SP, Brazil). Environmental Science and Pollution Research, 26: 4605-4617 https://doi.org/10.1007/s11356-018-3941-7

Moreira, L.B.; Leite, P.R.B.D.; Dias, M.L.; Martins, C.C.; Abessa, D.M.S. 2019a. Sediment quality assessment as potential tool for the management of tropical estuarine protected areas in SW $\begin{array}{lllll}\text { Atlantic, } & \text { Brazil. } & \text { Ecological } & \text { Indicators, } & \text { 101: }\end{array}$ https://doi.org/10.1016/j.ecolind.2018.12.052

Perina, F. C., Torres, R. J., Mozeto, A. A., Nascimento, M. R. L., \& de Souza Abessa, D. M. (2018). Sediment quality assessment of the tributaries of the Santos-São Vicente Estuarine SystemBrazil. Ecotoxicology and Environmental Contamination, 13(2), 25-38.

Pozo, H. V., Davanso, M. B., Moreira, L. B., \& Abessa, D. M. S. (2011). Toxicidade aguda de sedimentos na área de influência de uma marina no canal da Bertioga. IN. Simpósio Brasileiro de Oceanografia, 5 .

Ribeiro, T. S., Carvalho, D. P., Guimarães, M. T., Campina, N. N., Lobarinhas, M. R., Lopes, A. L. J., ... \& Gomes, A. (2016). Prevalence of hypertension and its associated factors in contaminated areas of the Santos-São Vicente Estuarine region and Bertioga, Brazil: 2006-2009. Environmental Science and Pollution Research, 23(19), 19387-19396.

Rizzo, A.E., Amaral, A.C.Z. 2001. Environmental variables and intertidal beach annelids of São Sebastião Channel (State of São Paulo, Brazil). Revista de Biologia Tropical 49: 849-857

Rodrigues, S. K., Abessa, D. M., \& Machado, E. C. (2013). Geochemical and ecotoxicological assessment for estuarine surface sediments from Southern Brazil. Marine Environmental Research, 91, 68-79.

Rodrigues, S.K.; Abessa, D.M.S.; Costa, E.M. 2013. Geochemical and ecotoxicological assessment for estuarine surface sediments from southern Brazil. Marine Environmental Research, 91: 68-79. http://dx.doi.org/10.1016/j.marenvres.2013.02.005

São Paulo, Estado, 2008b. Decreto $N^{\circ} 53.528$, de 8 de Outubro de 2008. Cria o Mosaico das Ilhas e Áreas Marinhas Protegidas do Litoral Paulista, e dá providências correlatas. Available at: https://www.al.sp.gov.br/repositorio/legislacao/decreto/2008/decreto-53528-08.10.2008.html (Accessed on August 1st, 2020).

São Paulo, Estado. 1977. Decreto N 10.251, de 30 de Agosto de 1977. Cria o Parque Estadual da Serra do Mar e dá providências correlatas. Available at: http://www.al.sp.gov.br/repositorio/legislacao/decreto/1977/decreto-10251-30.08.1977.html (Accessed on August 1st, 2020).

São Paulo, Estado. 2008a. Decreto No 53.526, de 08 de Outubro de 2008. Cria a Área de Proteção Ambiental Marinha do Litoral Centro, e dá providências correlatas. Available at: 
https://www.al.sp.gov.br/repositorio/legislacao/decreto/2008/decreto-53526-08.10.2008.html (Accessed on August 1st, 2020)

Sousa, E. C. P. M. D., Zaroni, L. P., Gasparro, M. R., \& Pereira, C. D. S. (2014). Review of ecotoxicological studies of the marine and estuarine environments of the Baixada Santista (São Paulo, Brazil). Brazilian Journal of Oceanography, 62(2), 133-147.

Wentworth, C. K. (1922). A scale of grade and class terms for clastic sediments. The Journal of Geology, 30(5), 377-392.

Zaroni, L. P. (2006). Avaliação da qualidade do sedimento marinho e estuarino no município de Bertioga-SP (Doctoral dissertation, IO/USP). 